Research Article

\title{
Tillage Effects on Soil Biochemical Properties and Maize Grown in Latosolic Red Soil of Southern China
}

\author{
Evans Asenso $\mathbb{D}^{1},{ }^{1}$ Jiuhao Li $\mathbb{D},{ }^{1}$ Lian Hu, ${ }^{2}$ Fuseini Issaka $\left(\mathbb{D},{ }^{3}\right.$ Kai Tian, ${ }^{1}$ Lina Zhang, \\ Luyong Zhang, ${ }^{1}$ and Haibo Chen ${ }^{2}$ \\ ${ }^{1}$ College of Water Conservancy and Civil Engineering, South China Agricultural University, Guangdong 510642, China \\ ${ }^{2}$ College of Engineering, South China Agricultural University, Guangdong 510642, China \\ ${ }^{3}$ College of Natural Resource and Environment, South China Agricultural University, Guangdong 510642, China
}

Correspondence should be addressed to Evans Asenso; evansasenso@yahoo.com and Jiuhao Li; jhli@scau.edu.cn

Received 17 May 2018; Accepted 4 September 2018; Published 8 October 2018

Academic Editor: Amaresh K. Nayak

Copyright ( 2018 Evans Asenso et al. This is an open access article distributed under the Creative Commons Attribution License, which permits unrestricted use, distribution, and reproduction in any medium, provided the original work is properly cited.

Based on the hypothesis that soil biochemical and maize yield components should be affected by different tillage methods, a field experiment was conducted to study the effects of subsoiling (SS), two passes of rotary tillage (2RT), two passes of rotary tillage + subsoiling (2RTSS), and zero tillage (ZT) on distribution of organic C, available NPK and soil enzyme, and its effects on maize yield in latosolic red soil of southern China in 2016 and 2017. ZT treatment had significantly higher organic C and available NPK than the other treatments, whereas the SS treatment had higher concentration of soil urease, catalase, and acid phosphatase. Also, maximum grain yield, dry matter, harvest index, and 1000-grain weight were recorded under SS treatment. Overall, although ZT facilitated more organic C and available NPK, soil with ZT had lower soil enzyme and maize yield components compared to SS treatment, and therefore SS treatment could be exploited as a strategy for soil health and productivity resulting in a sustainable agricultural system.

\section{Introduction}

Increase in world population has led to intensive farming systems resulting in an increase in high level of food security [1-4]. However, intensive farming is characterized by environmental degradations like freshwater pollution through nitrate leaching, fade of biodiversity, and increase of soil erosion $[3,5,6]$. The proper use of the plant nutrients for agricultural production is of importance to reduce the negative impacts on the environment caused by unsustainable farming systems [3,7]. Tillage practices in cropping systems have been part of most agricultural systems throughout history [8]. Different studies found that tillage has a negative impact on soil microbial biomass, community structure, and enzymatic activities [9-11]. Álvaro-Fuentes et al. [9] observed significant differences for tillage and depth in microbial biomass carbon and soil enzyme activities, finding a reduction in the surface layer with tillage but an increase in the $10-25 \mathrm{~cm}$ layer and no difference below the $25 \mathrm{~cm}$ soil depth. In comparison with conventional tillage, conservation tillage and no-tillage were found to increase soil bulk density and penetration resistance across the tillage layer [12-14] to increase soil water content [13-15], to reduce erosion [15], to improve soil structure $[16,17]$, and to increase microbial component and cation exchange capacity [18].

Several researchers observed an increase of soil organic matter (SOM) and carbon (SOC) with conservation tillage practices in the top soil layer [19-23]. In the lower soil layers, no difference or a decrease in SOC with conservation tillage were found, suggesting a balanced budget across the soil profile $[9,10]$. The tillage impact on nutrient redistribution and availability on plant nutrient uptake is much less covered in the literature compared to the impact on soil physical properties. In general, tillage improves the decomposition of crop residues by facilitating contact between plant tissue and soil aggregate surfaces, the primary biome of soil microorganisms $[24,25]$. In addition, tillage distributes 
organic matter in the soil and thus improves the availability of nutrients for plant growth through the formation of clayhumus complexes and the increase of charged surfaces for nutrient binding. Accumulation of considerable amounts of total nitrogen, phosphorus $(\mathrm{P})$, and potassium with conservation tillage was observed $[26,27]$. However, Calegari et al. [26] found in the same soil profile higher availability of phosphorous $(\mathrm{P})$ and potassium $(\mathrm{K})$ below the $10 \mathrm{~cm}$ layer. The presence of higher amount of nutrients in the very top soil $(0-5 \mathrm{~cm})$ under conservation tillage is also supported by different long-term experiments $[28,29,30]$. On the contrary, Roldán et al. [10] observed no tillage impact on available $P$.

Consequently, the understanding of nutrient availability and crop nutrient uptake for agricultural production requires in-depth knowledge of different and complex interacting processes among soil, plant, and environment. Thus, this study was to investigate the effects of tillage on soil biochemical properties and maize grown in latosolic red soil of Southern China.

\section{Materials and Methods}

2.1. Study Site. The field experiment was conducted during the 2016 maize growing seasons. The site is located at the farm of Wufengtai Agricultural Investment Co. Ltd., Lianping County, Heyuan City, Guangdong Province, China, at latitude $24^{\circ} 9^{\prime} 25^{\prime \prime} \mathrm{N}$, longitude $114^{\circ} 23^{\prime} 43^{\prime \prime} \mathrm{E}$, and at the altitude of $121 \mathrm{~m}$. The area belongs to the central subtropical monsoon climate, with abundant sunshine and rainfall. The annual average temperature is $18.0^{\circ} \mathrm{C}-20.7^{\circ} \mathrm{C}$, the annual average total sunshine hours are 1659.8 hours, and the annual average rainfall is $1779.7 \mathrm{~mm}$. May and June are the most concentrated period of rainfall, and the intensity has always been great. However, lowest are recorded in August. The basic characteristics of the soil are shown in Table 1 . The annual average humidity is $79 \%$, and the average frost day of each year is 65 days.

Before the establishment of this tillage experiment, the field had undergone a middle-term (7 years) consistence tillage practice for continuing maize cultivation.

2.2. Experimental Design. The experiments were laid out in a randomized complete block design (RCBD) with three repeats each. The field experiment involved two passes of rotary tillage (2RT at $20 \mathrm{~cm}$ ), subsoiling (SS at $40 \mathrm{~cm}$ ), two passes of rotary + subsoiling (2RTSS at 20 and $40 \mathrm{~cm}$ respectively), and zero tillage (ZT). Each treatment plot was measured in $1.5 \times 100 \mathrm{~m}^{2}$ area. In both seasons, the hybrid Yue Tian 26 (super sweet corn single-cross variety) was sown at a density of 44,400 plant ha $\mathrm{h}^{-1}$ during the two growing seasons with seed moisture and germination percentage of 15 and $90 \%$, respectively. Seeds were sown at $0.3 \mathrm{~m}$ within rows and $0.5 \mathrm{~m}$ between rows with the help of a 2-rows corn planter (2BMQE-2A Corn Planter), respectively. Organic fertilizer (pig manure) of $15000 \mathrm{~kg} \cdot \mathrm{ha}^{-1}$ applied in $7 \mathrm{~cm}$ depth was incorporated into the soil with a compound fertilizer of $220 \mathrm{~kg} \cdot \mathrm{N} \cdot \mathrm{ha}^{-1}, \quad 80 \mathrm{~kg} \cdot \mathrm{P}_{2} \mathrm{O}_{5} \cdot \mathrm{ha}^{-1}, \quad$ and
$150 \mathrm{~kg} \cdot \mathrm{K}_{2} \mathrm{O} \cdot \mathrm{ha}^{-1}$ as the basal fertilizer. Disease, pest, and weed control were performed according to the general local practices and recommendation. All other necessary operations except those under study were kept normal and uniform for all treatments.

2.3. Soil Sampling and Analyses. To determine the physical, chemical, and biological properties of the experimental site, composite soil samples was collected from 0 to $40 \mathrm{~cm}$ (i.e. $0-10,10-20,20-30$, and $30-40 \mathrm{~cm}$ ) depth before the start and after harvest of the maize crop. The soil of the experimental site is latosolic red soil (Orthic Acrisol, FAOUNESCO system) derived from quaternary red earth with a sandy-loam texture (58\% sand, $19 \%$ silt, and $23 \%$ clay). The soil sample was analyzed in the laboratory for dry bulk density, soil porosity, organic $\mathrm{C}$, and available NPK. The mean bulk density and porosity of the $0-40 \mathrm{~cm}$ top soil zone were $1.38 \mathrm{~g} \cdot \mathrm{cm}^{-3}$ and $46.15 \%$, respectively. The basic mean of the chemical and biological properties of the soil in $0-40 \mathrm{~cm}$ is presented in Table $1 . \mathrm{pH}$ was determined using the combined glass-electrode method [31, 32]. Urease activity was determined by the colorimetric method $[33,34]$; acid phosphatase was measured by the phenyl diphenyl phosphate colorimetric method [35, 36]; catalase activity determined by Yan [37]; organic $\mathrm{C}$ and available $\mathrm{N}$ by Bao [38]; available $\mathrm{P}$ was determined by Bray No. 1 extract method [39]; and available $\mathrm{K}$ was determined by the colorimetric method [40].

2.4. Statistical Analysis. The analysis of variance for various soil chemical and biological characteristics was performed statistically using randomized complete block design (RCBD) as described in [41]. Duncan's multiple range test (DMRT) at $5 \%$ probability was performed to compare the means of different treatments by using the computer software IBM SPSS Statistics 23.0.

\section{Results}

3.1. Soil Physical Properties. The bulk density and porosity were significantly higher under ZT and SS treatments, respectively, in both years. The bulk density was greater at all tillage treatments in the growing seasons. The greatest bulk density $\left(1.47\right.$ and $\left.1.50 \mathrm{~g} \cdot \mathrm{cm}^{-3}\right)$ and the greatest increase of 6.52 and $8.70 \%$ were observed under ZT treatment in the layer of $0-40 \mathrm{~cm}$, respectively, in both years, whilst the lowest values 1.4 and $1.42 \mathrm{~g} \cdot \mathrm{cm}^{-3}$ were observed under SS treatment in $0-40 \mathrm{~cm}$ soil depth in the lowest increase of 1.45 and $2.90 \%$ in both years, respectively (Table 2 ). Average increase of 4.34 and $4.83 \%$ was observed under 2RTSS and $2 \mathrm{RT}$ treatment in $0-40 \mathrm{~cm}$ soil depth in the growing season.

Soil porosity significantly differed among the treatments, the highest 47.76 and $47.02 \%$ with the highest increase of 3.49 and $1.89 \%$ were observed under SS treatment in the depth of $0-40 \mathrm{~cm}$ for both years, respectively, followed by 46.83 and $46.27 \%$ in the increase of 1.47 and $0.26 \%$ in 
TABLe 1: Basic chemical and biological characteristics of the soil.

\begin{tabular}{cccccccc}
\hline $\mathrm{pH}$ & $\mathrm{SOC}\left(\mathrm{g} \mathrm{kg}^{-1}\right)$ & \multicolumn{3}{c}{ Available $\left({\left.\mathrm{g} \cdot \mathrm{kg}^{-1}\right)}^{2}\right.$} & $\begin{array}{c}\text { Urease }\left[\mathrm{NH}_{4}^{+}-\mathrm{N}\right] \\
\left(\mathrm{mg} \mathrm{kg}^{-1}\right)\end{array}$ & $\begin{array}{c}\text { Catalase }\left[0.1 \mathrm{NKMnO}_{4}\right] \\
\left(\mathrm{mL} \mathrm{g}^{-1}\right)\end{array}$ & $\begin{array}{c}\text { Acid Phosphatase }\left[\mathrm{P}_{2} \mathrm{O}_{5}\right] \\
\left(\mathrm{mg} \mathrm{kg}^{-1}\right)\end{array}$ \\
\hline 4.73 & 12.28 & 105.75 & 68.05 & 185.26 & 241.15 & 1.28 & 281.42 \\
\hline
\end{tabular}

TABLE 2: Effects of tillage practices on soil physical properties in two years.

\begin{tabular}{|c|c|c|c|c|c|}
\hline \multirow{2}{*}{ Depth $(\mathrm{cm})$} & \multirow{2}{*}{ Treatment } & \multicolumn{2}{|c|}{ Bulk density $\left(\mathrm{g} \cdot \mathrm{cm}^{-3}\right)$} & \multicolumn{2}{|c|}{ Porosity (\%) } \\
\hline & & 2016 & 2017 & 2016 & 2017 \\
\hline \multirow{4}{*}{$0-10$} & $2 \mathrm{RT}$ & $1.25 \mathrm{~b}$ & $1.27 \mathrm{~b}$ & $53.36 \mathrm{~b}$ & $52.61 \mathrm{~b}$ \\
\hline & 2RTSS & $1.24 \mathrm{~b}$ & $1.26 \mathrm{~b}$ & $53.73 \mathrm{~b}$ & $52.99 \mathrm{~b}$ \\
\hline & SS & $1.21 \mathrm{c}$ & $1.24 \mathrm{C}$ & 54.85 a & $53.73 \mathrm{a}$ \\
\hline & $\mathrm{ZT}$ & $1.28 \mathrm{a}$ & $1.31 \mathrm{a}$ & $52.24 \mathrm{c}$ & $51.12 \mathrm{c}$ \\
\hline \multirow{4}{*}{$10-20$} & $2 \mathrm{RT}$ & $1.38 \mathrm{~b}$ & $1.40 \mathrm{~b}$ & $48.51 \mathrm{~b}$ & $47.76 \mathrm{c}$ \\
\hline & 2RTSS & $1.36 \mathrm{c}$ & $1.38 \mathrm{c}$ & $49.25 \mathrm{~b}$ & $48.51 \mathrm{~b}$ \\
\hline & SS & $1.33 \mathrm{~d}$ & $1.35 \mathrm{~d}$ & 50.37 a & $49.63 \mathrm{a}$ \\
\hline & $\mathrm{ZT}$ & $1.48 \mathrm{a}$ & $1.51 \mathrm{a}$ & $44.78 \mathrm{c}$ & $43.66 \mathrm{~d}$ \\
\hline \multirow{4}{*}{$20-30$} & $2 \mathrm{RT}$ & $1.56 \mathrm{a}$ & $1.57 \mathrm{a}$ & $41.79 \mathrm{~b}$ & $41.42 \mathrm{~b}$ \\
\hline & 2RTSS & $1.55 \mathrm{a}$ & $1.56 \mathrm{a}$ & $42.16 \mathrm{~b}$ & $41.79 \mathrm{~b}$ \\
\hline & SS & $1.53 \mathrm{~b}$ & $1.54 \mathrm{~b}$ & 42.91 a & 42.54 a \\
\hline & $\mathrm{ZT}$ & $1.56 \mathrm{a}$ & $1.58 \mathrm{a}$ & $41.79 \mathrm{~b}$ & $41.04 \mathrm{~b}$ \\
\hline \multirow{4}{*}{$30-40$} & 2RT & $1.56 \mathrm{~b}$ & $1.57 \mathrm{~b}$ & $41.79 \mathrm{~b}$ & $41.42 \mathrm{~b}$ \\
\hline & 2RTSS & $1.55 \mathrm{~b}$ & $1.56 \mathrm{bc}$ & $42.16 \mathrm{~b}$ & $41.79 \mathrm{ab}$ \\
\hline & SS & $1.53 \mathrm{c}$ & $1.55 \mathrm{c}$ & $42.91 \mathrm{a}$ & $42.16 \mathrm{a}$ \\
\hline & $\mathrm{ZT}$ & $1.57 \mathrm{a}$ & $1.59 \mathrm{a}$ & $41.42 \mathrm{c}$ & $40.67 \mathrm{c}$ \\
\hline
\end{tabular}

Values within a column in the same year followed by the same letters are not significantly different $(P<0.05)$. 2RT: two passes of rotary tillage; 2RTSS: two passes of rotary tillage + subsoiling; SS: subsoiling; ZT: zero tillage.

0-40 cm for both years, respectively, whilst the lowest 45.06 and $44.12 \%$ was observed under $\mathrm{ZT}$ treatment in the lowest decrease of 4.74 and $4.60 \%$ in $0-40 \mathrm{~cm}$, respectively (Table 2).

3.2. Soil Chemical Properties. According to the one-way ANOVA, pH and available $\mathrm{N}, \mathrm{P}$, and $\mathrm{K}$ were influenced by different tillage methods. Soil $\mathrm{pH}$ varied considerably $(P \leq 0.05)$ among tillage practices. This, at the end of the study, $\mathrm{pH}$ was increased due to tillage methods. The highest $\mathrm{pH}$ of 4.77 was recorded among 2RT, 2RTSS, and SS treatments in $0-40 \mathrm{~cm}$ in 2016 compared with $4.80,4.75$, and 4.77 under 2RT, 2RTSS, and SS treatment in $0-40 \mathrm{~cm}$, respectively, in 2017, whilst the lowest pH 4.74 in 2016 and 4.73 in 2017 under ZT treatment (Figure 1).

Soil organic C was significantly different in all depths in 2017 compared to in 2016; however, the highest values (12.77 and $12.82 \mathrm{~g} \cdot \mathrm{kg}^{-1}$ ) statistically with a highest increase of 3.99 and $4.40 \%$ in $0-40 \mathrm{~cm}$ in soil depth were recorded under ZT treatment, respectively, in 2016 and 2017 followed by 11.71 and $11.79 \mathrm{~g} \cdot \mathrm{kg}^{-1}$ under SS treatment in $0-40 \mathrm{~cm}$, whilst the lowest 10.47 and $10.44 \mathrm{~g} \cdot \mathrm{kg}^{-1}$ in the lowest decrease of 17.29 and $17.62 \%$ was recoded under 2 RTSS in $0-40 \mathrm{~cm}$ soil depth in both years, respectively (Figure 2(a)).

ZT treatment resulted in the highest activity of available $\mathrm{N}$ (117.90 and $\left.117.98 \mathrm{mg} \cdot \mathrm{kg}^{-1}\right)$ which markedly increased by 11.49 and $11.57 \%$, respectively, followed by 108.48 and $108.16 \mathrm{mg} \cdot \mathrm{kg}^{-1}$ under 2RT treatment (2.58 and $2.28 \%$ ), and the lowest 103.14 and $101.95 \mathrm{mg} \cdot \mathrm{kg}^{-1}$ observed under 2RTSS treatment in the decrease of 2.53 and $3.73 \%$ in $0-40 \mathrm{~cm}$ in soil depth in both years, respectively (Figure 2(b)).

Available $\mathrm{P}$ content was significantly varied $(P \leq 0.05)$ among the different tillage practices. The highest $76.70 \mathrm{mg} \cdot \mathrm{kg}^{-1}$ in 2016 and $81.1 \mathrm{mg} \cdot \mathrm{kg}^{-1}$ in 2017 available P were observed under ZT treatment, followed by $70.88 \mathrm{mg} \cdot \mathrm{kg}^{-1}$ in 2016 and $72.18 \mathrm{mg} \cdot \mathrm{kg}^{-1}$ in 2017 under SS treatment, and the lowest (55.48 and $55.39 \mathrm{mg} \cdot \mathrm{kg}^{-1}$, respectively, in both years) were recorded under 2RTSS compared to the initial value in $0-40 \mathrm{~cm}$ soil depth (Figure 2(c)). Consequently, there was a higher increase of $12.71 \%$ in 2016 and $19.18 \%$ in 2017 under ZT treatment followed by $4.16 \%$ in 2016 and $6.07 \%$ in 2017 under SS treatment, whilst 2RTSS treatment markedly recorded the highest reduction of 22.66 and $22.86 \%$ in $0-$ $40 \mathrm{~cm}$ soil depth in both years, respectively.

The highest available K (208.87 and $\left.209.38 \mathrm{mg} \cdot \mathrm{kg}^{-1}\right)$ content was recorded under the ZT treatment followed by 188.20 and $189.36 \mathrm{mg} \cdot \mathrm{kg}^{-1}$ under $2 \mathrm{RT}$ treatment in $0-40 \mathrm{~cm}$ in soil depth for 2016 and 2017, respectively. The lowest available $\mathrm{K}$ (174.26 and $\left.174.62 \mathrm{mg} \cdot \mathrm{kg}^{-1}\right)$ was noted in the 2RTSS treatment (Figure 2(d)). This therefore resulted in a higher increase of 12.74 and $13.04 \%$ under ZT treatment, followed by 1.59 and $2.21 \%$ under $2 \mathrm{RT}$ treatment with the lowest reduction (6.31 and 6.09\%) recorded under 2RTSS in 0-40 cm soil depth for both years, respectively.

3.3. Soil Biological Properties. Tillage practice had a significant effect on enzyme activities $(P \leq 0.05)$ during the 


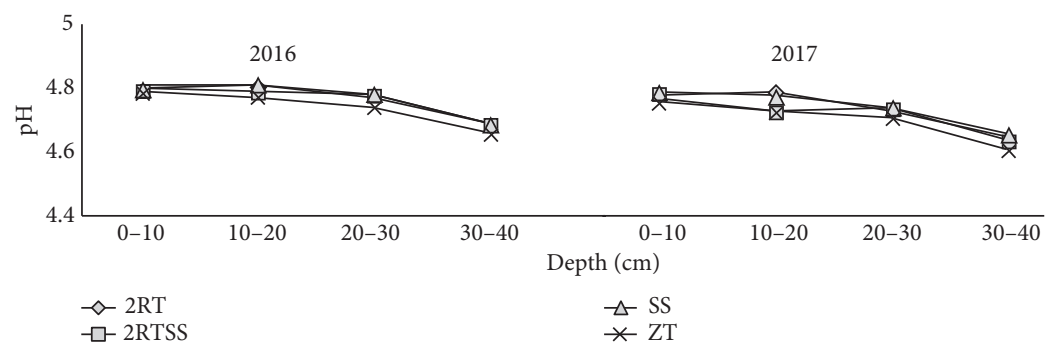

FIGURE 1: Effects of tillage methods on soil pH (2RT: two passes of rotary tillage; 2RTSS: two passes of rotary tillage + subsoiling; SS: subsoiling; ZT: zero tillage).

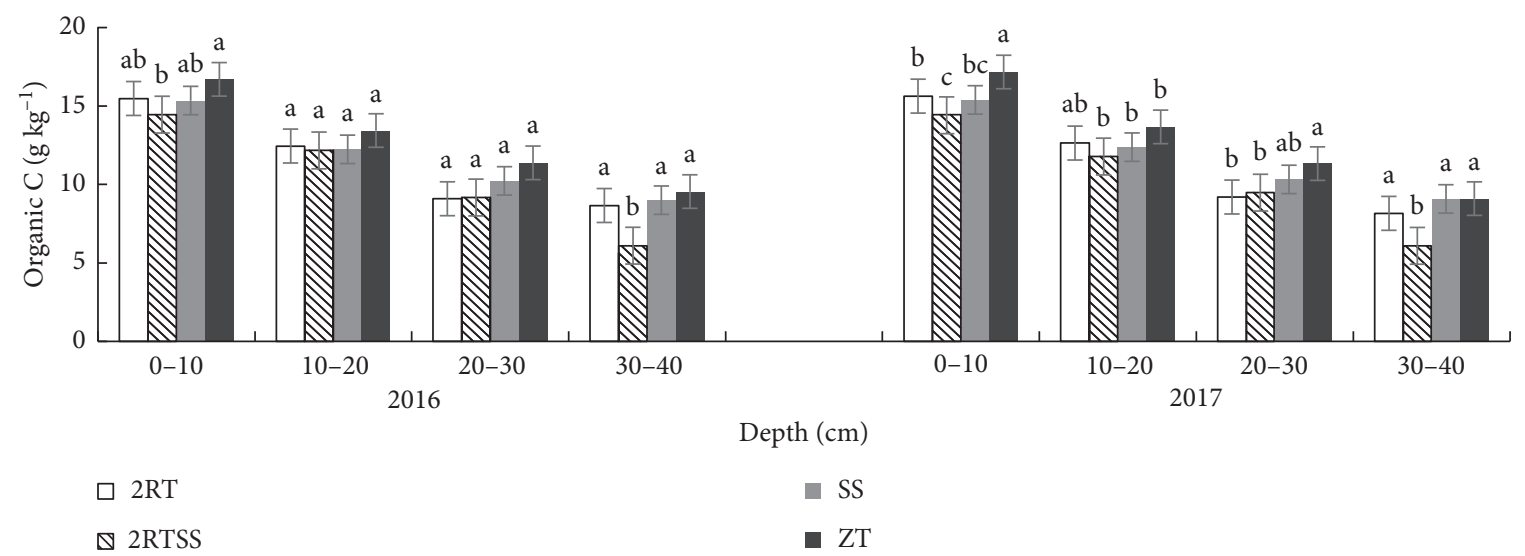

(a)

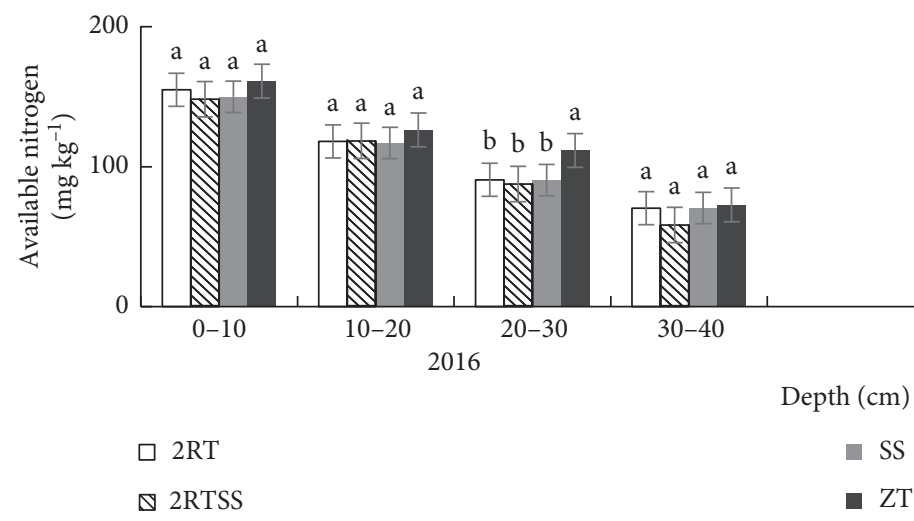

(b)

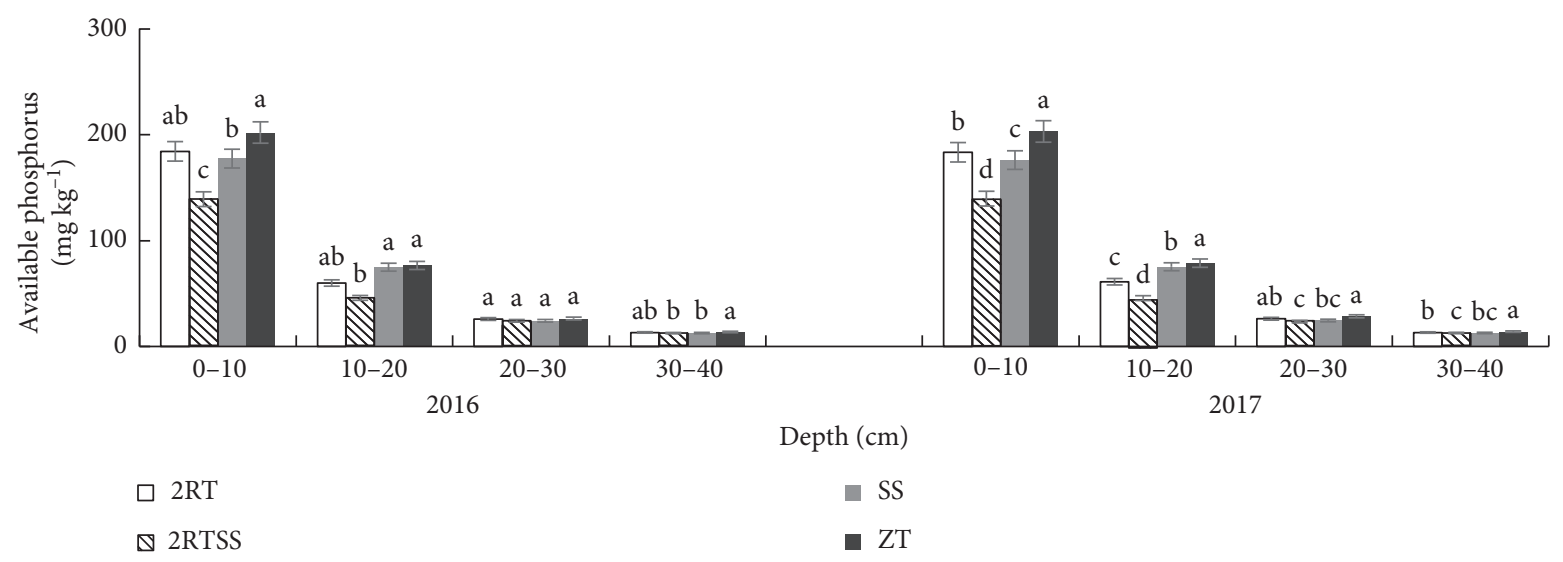

(c)

Figure 2: Continued. 


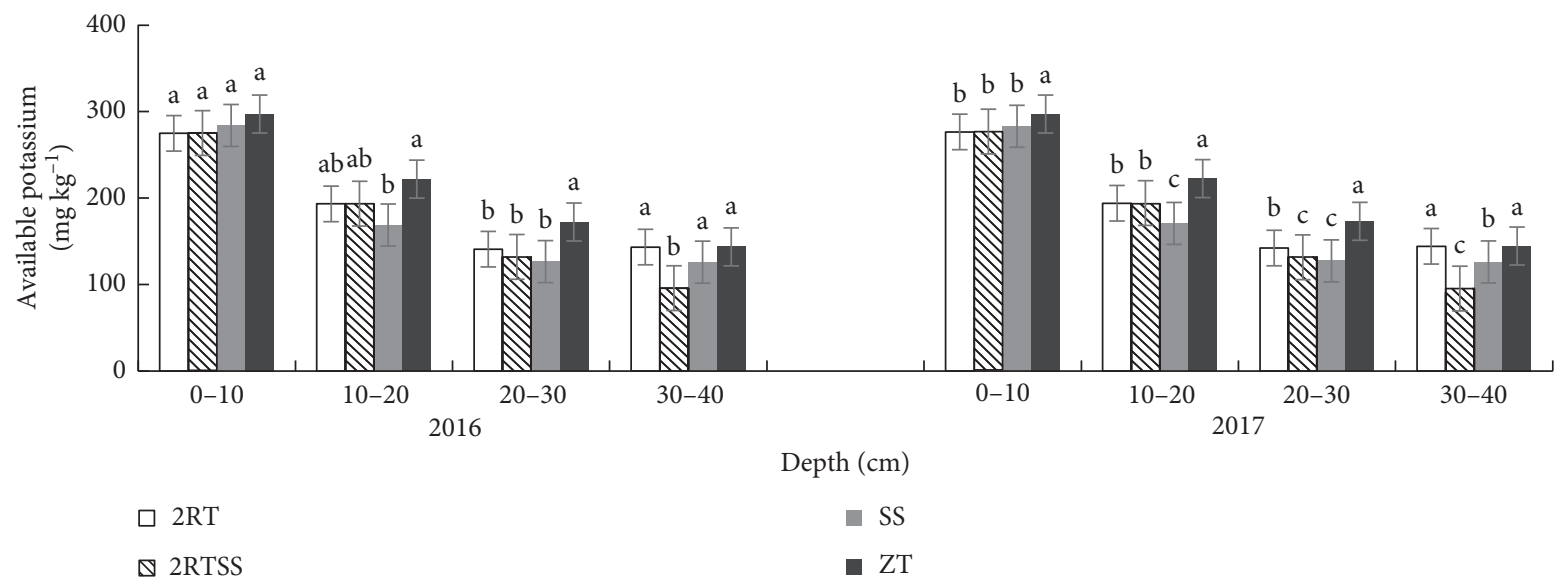

(d)

Figure 2: Effects of tillage methods on organic carbon (a), available nitrogen (b), available phosphorus (c), available potassium (d) due to different tillage practices in 2016 and 2017 season (2RT: two passes of rotary tillage; 2RTSS: two passes of rotary tillage + subsoiling; SS: subsoiling; ZT: zero tillage. Means $\pm \mathrm{SE}$ are shown in error bar $(P<0.05)$.

TABLE 3: Effects of tillage practices on enzymatic activities in the soil in two years.

\begin{tabular}{|c|c|c|c|c|c|c|c|}
\hline \multirow[b]{2}{*}{ Depth $(\mathrm{cm})$} & \multirow[b]{2}{*}{ Treatment } & \multicolumn{3}{|c|}{2016} & \multicolumn{3}{|c|}{2017} \\
\hline & & $\begin{array}{c}\text { Urease } \\
{\left[\mathrm{NH}_{4}^{+}-\mathrm{N}\right]} \\
\left(\mathrm{mg} \cdot \mathrm{kg}^{-1}\right)\end{array}$ & $\begin{array}{c}\text { Catalase } \\
{\left[0.1 \mathrm{NKMO}_{4}\right]} \\
\left(\mathrm{mL} \cdot \mathrm{kg}^{-1}\right)\end{array}$ & $\begin{array}{c}\text { Acid } \\
\text { Phosphatase } \\
{\left[\mathrm{P}_{2} \mathrm{O}_{5}\right]} \\
\left(\mathrm{mL} \cdot \mathrm{kg}^{-1}\right)\end{array}$ & $\begin{array}{c}\text { Urease } \\
{\left[\mathrm{NH}_{4}^{+}-\mathrm{N}\right]} \\
\left.\left(\mathrm{mg} \cdot \mathrm{kg}^{-1}\right)\right]\end{array}$ & $\begin{array}{c}\text { Catalase } \\
{\left[0.1 \mathrm{NKMO}_{4}\right]} \\
\left.\left(\mathrm{mL} \cdot \mathrm{kg}^{-1}\right)\right]\end{array}$ & $\begin{array}{l}\text { Acid Phosphatase } \\
\left.\left[\mathrm{P}_{2} \mathrm{O}_{5}\right]\left(\mathrm{mg} \cdot \mathrm{kg}^{-1}\right)\right]\end{array}$ \\
\hline \multirow{4}{*}{$0-10$} & $2 \mathrm{RT}$ & $406.46 \mathrm{a}$ & $1.95 \mathrm{a}$ & $412.22 \mathrm{a}$ & $408.63 \mathrm{~b}$ & $2.05 \mathrm{a}$ & $423.17 \mathrm{c}$ \\
\hline & 2RTSS & $418.45 \mathrm{~b}$ & $1.23 \mathrm{a}$ & $426.17 \mathrm{a}$ & $420.68 \mathrm{~b}$ & $1.80 \mathrm{a}$ & $428.26 \mathrm{bc}$ \\
\hline & SS & 437.22 a & $2.05 \mathrm{a}$ & 448.37 a & $438.56 \mathrm{a}$ & $2.18 \mathrm{a}$ & $450.23 \mathrm{a}$ \\
\hline & $\mathrm{ZT}$ & $419.67 \mathrm{~b}$ & $2.01 \mathrm{a}$ & $430.38 \mathrm{a}$ & $422.05 \mathrm{~b}$ & $2.11 \mathrm{a}$ & $431.66 \mathrm{~b}$ \\
\hline \multirow{4}{*}{$10-20$} & 2RT & $224.25 \mathrm{~b}$ & $1.30 \mathrm{a}$ & $274.43 \mathrm{a}$ & $226.1 \mathrm{c}$ & $1.35 \mathrm{a}$ & $277.07 \mathrm{~b}$ \\
\hline & 2RTSS & $233.70 \mathrm{~b}$ & $1.23 \mathrm{a}$ & $313.69 \mathrm{a}$ & $235.25 \mathrm{~b}$ & $1.31 \mathrm{a}$ & $314.36 \mathrm{ab}$ \\
\hline & SS & $278.49 \mathrm{a}$ & $1.44 \mathrm{a}$ & 348.82 a & 283.92 a & $1.66 \mathrm{a}$ & 345.83 a \\
\hline & $\mathrm{ZT}$ & $236.11 \mathrm{~b}$ & $1.44 \mathrm{a}$ & $334.5 \mathrm{a}$ & $239.15 \mathrm{~b}$ & $1.51 \mathrm{a}$ & $335.48 \mathrm{a}$ \\
\hline \multirow{4}{*}{$20-30$} & 2RT & $165.27 \mathrm{~b}$ & $0.86 \mathrm{ab}$ & $225.09 \mathrm{a}$ & $167.15 \mathrm{~b}$ & $0.94 \mathrm{~b}$ & $227.93 \mathrm{~b}$ \\
\hline & 2RTSS & $125.93 \mathrm{c}$ & $0.78 \mathrm{~b}$ & $216.90 \mathrm{a}$ & $127.93 \mathrm{c}$ & $0.81 \mathrm{c}$ & $217.58 \mathrm{~b}$ \\
\hline & SS & 226.47 a & $1.12 \mathrm{a}$ & 242.94 a & 228.07 a & $1.14 \mathrm{a}$ & 251.73 a \\
\hline & $\mathrm{ZT}$ & $212.79 \mathrm{a}$ & $0.94 \mathrm{a}$ & $235.54 \mathrm{a}$ & $224.22 \mathrm{a}$ & $0.98 \mathrm{~b}$ & $237.2 \mathrm{a}$ \\
\hline \multirow{4}{*}{$30-40$} & 2RT & $112.08 \mathrm{bc}$ & $0.82 \mathrm{~b}$ & $126.46 \mathrm{~b}$ & $114.70 \mathrm{bc}$ & $0.89 \mathrm{~b}$ & $128.00 \mathrm{c}$ \\
\hline & 2RTSS & $111.07 \mathrm{c}$ & $0.80 \mathrm{~b}$ & $122.63 \mathrm{~b}$ & $113.32 \mathrm{c}$ & $0.86 \mathrm{~b}$ & $124.29 \mathrm{~d}$ \\
\hline & SS & $116.94 \mathrm{a}$ & $1.03 \mathrm{a}$ & $154.34 \mathrm{a}$ & $118.94 \mathrm{a}$ & $1.10 \mathrm{a}$ & $155.44 \mathrm{a}$ \\
\hline & $\mathrm{ZT}$ & $115.84 \mathrm{ab}$ & $0.96 \mathrm{a}$ & $150.48 \mathrm{a}$ & $117.07 \mathrm{ab}$ & $0.98 \mathrm{~b}$ & $151.96 \mathrm{~b}$ \\
\hline
\end{tabular}

Values within a column in the same year followed by the same letters are not significantly different $(P<0.05)$. 2RT: two passes of rotary tillage; 2RTSS: two passes of rotary tillage + subsoiling; SS: subsoiling; ZT: zero tillage.

growing seasons (Table 3). Urease under SS treatment was higher than under ZT, 2RT, and 2RTSS treatments. SS treatment recorded 264.78 and $267.37 \mathrm{mg} \cdot \mathrm{kg}^{-1}$ as the highest followed by 246.10 and $250.62 \mathrm{mg} \cdot \mathrm{kg}^{-1}$ under ZT treatment and the lowest $\left(227.02\right.$ and $\left.229.15 \mathrm{mg} \cdot \mathrm{kg}^{-1}\right)$ being recorded under $2 \mathrm{RT}$ in $0-40 \mathrm{~cm}$ soil depth in both seasons, respectively. Consequently, higher increase of 9.80 and $10.87 \%$ was recorded under SS treatment followed by 2.05 and $3.93 \%$ under ZT treatment; however, reduction of 6.22 and $5.24 \%$ was recorded under $2 \mathrm{RT}$ in $0-40 \mathrm{~cm}$ soil in both years, respectively (Table 3 ).
Acid phosphatase was significantly different in all depths in 2017 compared to in 2016; however, the highest values statistically $298.62 \mathrm{mg} \cdot \mathrm{kg}^{-1}$ in 2016 and $300.81 \mathrm{mg} \cdot \mathrm{kg}^{-1}$ in 2017 were recorded under SS treatment followed by $287.73 \mathrm{mg} \cdot \mathrm{kg}^{-1}$ in 2016 and $289.08 \mathrm{mg} \cdot \mathrm{kg}^{-1}$ under ZT treatment with the lowest $259.55 \mathrm{mg} \cdot \mathrm{kg}^{-1}$ in 2016 and $264.04 \mathrm{mg} \cdot \mathrm{kg}^{-1}$ in 2017 under $2 \mathrm{RT}$ treatment in $0-40 \mathrm{~cm}$ soil depth for both years, respectively (Table 3).

There were some significant differences among the catalase activities in both seasons $(P \leq 0.05)$; SS treatment recorded the highest catalase (1.41 and $\left.1.52 \mathrm{~mL} \cdot \mathrm{kg}^{-1}\right)$ 
followed by ZT treatment $\left(1.34\right.$ and $\left.1.40 \mathrm{~mL} \cdot \mathrm{kg}^{-1}\right)$ and the lowest 1.19 and $1.20 \mathrm{~mL} \cdot \mathrm{kg}^{-1}$ recorded under 2RTSS in 0$40 \mathrm{~cm}$ soil depth in both years, respectively (Table 3 ).

3.4. Maize Yield Component Analyses. Different tillage methods significantly affected grain yield during both years of study. The highest grain yields of 7.34 and 7.40 ton $\cdot \mathrm{ha}^{-1}$ were obtained in the case of SS treatment, and the minimum grain yields of 6.70 and $6.75 \mathrm{ton} \cdot \mathrm{ha}^{-1}$ were obtained under ZT treatment in 2016 and 2017, respectively (Table 4). However, regarding SS treatment, grain yield was increased by 9.55 and $9.63 \%$ in both seasons, respectively.

After harvesting of maize, total dry matter was noted, and the highest (19.21 ton $\cdot$ ha $^{-1}$ ) was recorded under SS treatment in both years followed by (18.78 and 18.79 ton $\cdot$ ha $^{-1}$ ) under 2RT treatment, respectively, for both years. The lowest dry matter values $17.87 \mathrm{ton} \cdot \mathrm{ha}^{-1}$ in 2016 and $17.85 \mathrm{ton} \cdot \mathrm{ha}^{-1}$ in 2017 were recorded from the ZT treatment. SS treatment improved the total biomass up to 7.50 and $7.62 \%$ than the ZT treatment in both years, respectively (Table 4 ).

Highest harvest index (38.22 and 38.50\%) was recorded from the SS treatment followed by 37.89 and $38.17 \%$ under 2RT treatment for both years, respectively. Lowest harvest index (37.48 and $37.80 \%$ ) was recorded from the SS treatment in both years, respectively. As regards, SS treatment improved the harvest index 1.97 and $1.85 \%$ than ZT treatment (Table 3 ) in respective years. A similar trend was observed in the 1000-grain weight, as the highest (297.41 and $302.35 \mathrm{~g}$ ) values were recorded under SS treatment followed by 283.70 and $288.41 \mathrm{~g}$ under $2 \mathrm{RT}$ treatment and the lowest 270.14 and $272.22 \mathrm{~g}$ under ZT treatment, respectively, for both years. The SS treatment improved the 1000-grain weight up to 10.09 and $11.07 \%$ than the ZT treatment in both years, respectively (Table 4 ).

3.5. Relationship among Variables and Hierarchical Analysis. Correlation analysis was conducted on the effects of the tillage methods on soil chemical and biological properties (Table 5). The results showed that that there was significant correlation between the chemical and biological properties; however, the highest significance at the 0.01 level was recorded between urease and available $\mathrm{N}$, whilst the lowest was recorded between available $\mathrm{P}$ and $\mathrm{pH}$.

In the hierarchical cluster analysis, the chemical and biological properties were grouped on the basis of their role in the transformation processes of their soil content. Generally, two clusters were obtained from the cluster analysis that was performed on the chemical and biological properties being studied (Figure 3). One included the $\mathrm{pH}$, catalase, soil organic matter, available $\mathrm{N}$, and $\mathrm{P}$, and the second included acid phosphatase, urease, and available potassium which showed a linkage between the soil properties.

\section{Discussion}

The statistical results of the study indicated that tillage methods significantly $(P \leq 0.05)$ affected bulk density and porosity. The bulk density was greater at all tillage treatments in the growing season. The greatest increase in bulk density of 6.52 and $8.70 \%$ was observed under ZT treatment in the layer of $0-40 \mathrm{~cm}$ in both years, respectively (Table 2); this might be due to the undisturbed soil. Similar results on the increase of soil bulk density were also reported by Kovac and Zak [42] and [43] confirms the upward trend of soil compaction and bulk density under the tillage practices. Rise in soil bulk density in the cultivated horizon on medium heavy soils has a negative effect on the growth and development of agricultural crops. The lowest average increase of bulk density 1.45 and $2.90 \%$ in both years, respectively (Table 2), was observed under SS treatment in $0-40 \mathrm{~cm}$ soil depth; this might be due to the loosening of the soil as a result of the lateral cut created by the implement which increases deposition of organic matter and water movement. Butorac et al. [44] observed the highest corn yield on Luvisol with the average bulk density of $1.40 \mathrm{Mg} \mathrm{m}^{-3}$, while a much lower yield was obtained with the bulk density of $1.60 \mathrm{Mg} \cdot \mathrm{m}^{-3}$. Soils with high bulk density of the subcultivated horizon have also poor internal drainage and are characterized by reduced root growth, resulting in a substantial yield decrease [45].

Tillage generally alters soil porosity [46] but its effects are quite transitory, which was reflected in the worsening soil physical condition of the conventional tillage treatment, for example, predominance of microporosity. The consistent improvement in overall soil porosity under SS treatment (Table 2) was most probably related to increased aggregate stability, enhanced by minimum tillage, residue cover, and biological activity. This treatment also had a better distribution of the various pore size classes which is very important for the crop growth, since it influences plant available water, soil aeration, through increased connectivity, drainage, and channeling for enhanced root development [47].

Tillage practices showed that soil $\mathrm{pH}$ had no significant difference in average in $0-40 \mathrm{~cm}$ soil depth as indicated in Figure 1 . This may be due to the fact that no limning material was applied as part of treatment. However, minimal increase difference was observed under ZT treatment in $0-40 \mathrm{~cm}$ soil depth compared to the initial pH of the soil in 2016. However, little difference in soil $\mathrm{pH}$ in zero-tillage practice was reported in the literature as compared with conventional practice $[48,49,50]$.

The highest increase (3.99 and $4.40 \%$ ) of organic C was observed under ZT treatment whilst the highest reduction of 17.29 and $17.62 \%$ in organic $C$ was observed under 2RTSS treatment in $0-40 \mathrm{~cm}$ soil depth in both years, respectively (Figure 2(a)). This may be due to the fact that the land was not disturbed which increased the buildup of soil organic matter, resulting in high organic carbon which reflects a reduced rate of leaching in the soil profile in the soil studied. Tillage systems (zero tillage) that reduce soil disturbance and residue incorporation have generally been observed to increase organic C. ZT has been reported to have resulted in increased in organic $C$ content which in turn enhances soil quality and resilience [51, 52].

Differences in available N (Figure 2(b)) among tillage systems are in agreement with those of other studies [50]. Available $\mathrm{N}$ was significantly higher in ZT treatment than in 
TABLE 4: Effects of tillage practices on maize yield component in two years.

\begin{tabular}{|c|c|c|c|c|c|}
\hline Year & Treatments & Dry matter (ton $\cdot$ ha $^{-1}$ ) & 1000-grain weight $(\mathrm{g})$ & Grain yield (ton $\cdot h^{-1}$ ) & Harvest index (\%) \\
\hline \multirow{4}{*}{2016} & 2RT & $18.78 \mathrm{~b}$ & $283.70 \mathrm{~b}$ & $7.11 \mathrm{~b}$ & 37.89 a \\
\hline & 2RTSS & $18.39 \mathrm{c}$ & $277.11 \mathrm{~b}$ & $6.92 \mathrm{~b}$ & $37.58 \mathrm{a}$ \\
\hline & SS & $19.21 \mathrm{a}$ & 297.41 a & $7.34 \mathrm{a}$ & $38.22 \mathrm{a}$ \\
\hline & $\mathrm{ZT}$ & $17.87 \mathrm{~d}$ & $270.14 \mathrm{c}$ & $6.70 \mathrm{c}$ & $37.48 \mathrm{a}$ \\
\hline \multirow{4}{*}{2017} & $2 \mathrm{RT}$ & $18.79 \mathrm{~b}$ & $288.41 \mathrm{~b}$ & $7.17 \mathrm{~b}$ & $38.17 \mathrm{a}$ \\
\hline & 2RTSS & $18.53 \mathrm{c}$ & $281.54 \mathrm{c}$ & $7.02 \mathrm{~b}$ & $37.87 \mathrm{a}$ \\
\hline & SS & $19.21 \mathrm{a}$ & $302.35 \mathrm{a}$ & $7.40 \mathrm{a}$ & $38.50 \mathrm{a}$ \\
\hline & ZT & $17.85 \mathrm{~d}$ & $272.22 \mathrm{~d}$ & $6.75 c$ & $37.80 \mathrm{a}$ \\
\hline
\end{tabular}

Values within a column in the same year followed by the same letters are not significantly different $(P<0.05)$. 2RT: two passes of rotary tillage; 2 RTSS: two passes of rotary tillage + subsoiling; SS: subsoiling; ZT: zero tillage.

TABLe 5: Pearson's correlation coefficients among chemical and biological activities under tillage methods.

\begin{tabular}{|c|c|c|c|c|c|c|c|}
\hline & $\mathrm{pH}$ & Organic C & Available N & Available P & Available K & Catalase & Acid phosphatase \\
\hline$\overline{\text { SOC }}$ & $0.728^{* *}$ & & & & & & \\
\hline AN & $0.814^{* *}$ & $0.934^{* *}$ & & & & & \\
\hline $\mathrm{AP}$ & $0.611^{* *}$ & $0.891^{* *}$ & $0.914^{* *}$ & & & & \\
\hline $\mathrm{AK}$ & $0.658^{* *}$ & $0.920^{* *}$ & $0.941^{* *}$ & $0.952^{* *}$ & & & \\
\hline $\mathrm{CT}$ & $0.697^{* *}$ & $0.896^{* *}$ & $0.955^{* *}$ & $0.950^{* *}$ & $0.960^{* *}$ & & \\
\hline $\mathrm{AcP}$ & $0.636^{* *}$ & $0.900^{* *}$ & $0.916^{* *}$ & $0.938^{* *}$ & $0.938^{* *}$ & $0.932 * *$ & \\
\hline UR & $0.808^{* *}$ & $0.916^{* *}$ & $0.967^{* *}$ & $0.910^{* *}$ & $0.937^{* *}$ & $0.957^{* *}$ & $0.921^{* *}$ \\
\hline
\end{tabular}

${ }^{* *}$ correlation is significant at the 0.01 level; OC: organic carbon; AN: available nitrogen; AP: available phosphorus; AK: available potassium; CT: catalase; AcP: acid phosphatase; UR: urease.

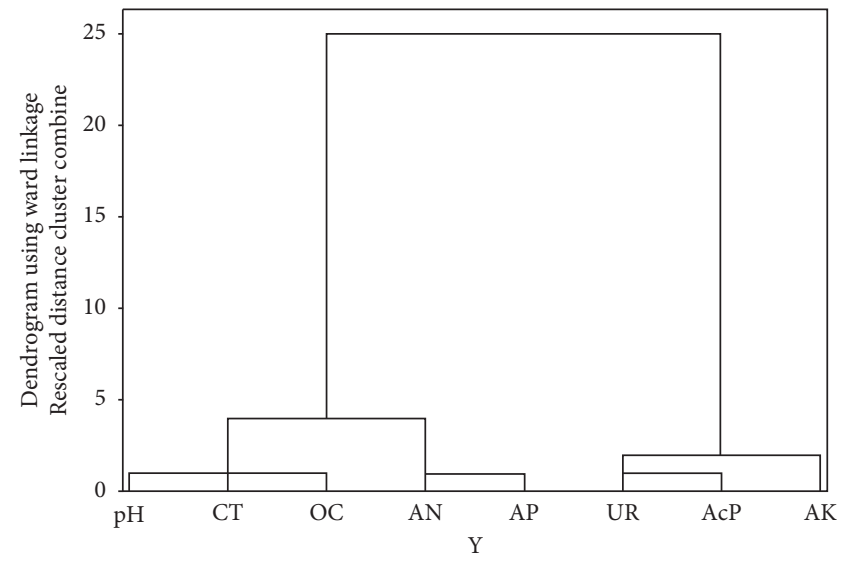

FIGURE 3: Dendrogram of the ward linkage from the hierarchical cluster analysis of soil properties; OC: soil organic carbon; AN available nitrogen; AP: available phosphorus; AK: available potassium; CT: catalase; AcP: acid phosphatase; UR: urease.

other treatments. Similarly, a study on Mollisols in Nebraska, available $\mathrm{N}$ was significantly greater under zero tillage than conventional tillage [53]. In another study, soil available $\mathrm{N}$ content was also significantly increased under zero or minimum tillage [50]. Higher available $\mathrm{N}$ in ZT treatment may be attributed to less loss through immobilization, volatilization, denitrification, and leaching [54], whereas alternate tillage practice and no disturbance of soil might lead to more loss of $\mathrm{N}$ through different mechanisms.

Available P and K (Figures 2(c) and (d)) were higher under ZT treatment probably due to higher soil organic C level and surface applied K and P fertilizers. Franzluebbers and Hons [49] and Zibilske et al. [55] reported that improvement of soil available $\mathrm{P}$ was due to redistribution or mining of $P$ at lower soil depths. Also, work done in $[56,57]$ showed a high amount of $\mathrm{P}$ under ZT treatment compared to the conventional tillage and have attributed this to an increase in contact time between $\mathrm{P}$ and soil particles [58]. In the present findings, the $\mathrm{K}$ concentrations were higher in $\mathrm{ZT}$ treatment. Yin and Vyn [60] also observed more soil $\mathrm{K}$ in case of ZT treatment as compared to SS treatment (Figure 2(d)).

Enzyme activities were generally higher in SS treatment than in the other treatments, and it may be that SS treatment loosens the soil and adds the organic matter resulting in higher organic $\mathrm{C}$ into the soil, which increased the abundance of soil microorganism. The more the microorganisms, the higher the soil enzyme activities. Also, the higher urease, acid phosphatase, and catalase (Table 3) could perhaps be partially explained by a flush of microbial activity directly after the tillage practice as a result of an increase in substrate and oxygen availability [61]. Jin et al., [62] also reported that SS treatment consistently had higher enzyme activities compared with other tillage practices [62]. The consistent ranking of enzyme activities between soil management practices demonstrates that the activities of these enzymes could be a potential indicator for the effects of changes in tillage on soil functioning and soil quality [62]. Also, the consistent higher values in enzyme activities resulted in higher productivity in our study which is supported by [62]. With the increase of soil depth, urease, catalase, and acid phosphatase activities all decreased (Table 3). Kheyrodin et al., [63], Deng Tabatabai [64], and Jin et al. [62] reported a decrease in urease, acid phosphatase, and catalase activities, respectively, with increasing soil depth. They thought 
this decrease may be associated with the decrease in organic carbon content. Most enzyme activities in the surface soil were higher than that in deep soil. This may be because there were more soil microorganisms and plant residues in the surface soil, which were the main parts of soil enzymes. For urease in the soil, SS treatment was most effective in 0$10 \mathrm{~cm}$. At this depth, urease activities of SS treatment increased by 81.31 and $81.86 \%$ higher than that of ZT treatment of 74.03 and $75.02 \%$, respectively, in both years. Catalase was also effective at SS treatment with an increase of 60.16 and $70.31 \%$ compared to 57.03 and $64.84 \%$ under ZT treatment in $0-10 \mathrm{~cm}$ depth in both years, respectively. Similarly, SS treatment had the greatest effect on the activities of acid phosphatase in $0-10 \mathrm{~cm}$, and 59.32 and $59.99 \%$ increase were observed compared to 52.93 and $53.39 \%$ under ZT treatment in both years, respectively.

Highest yield of maize (7.34 and 7.40 ton.ha ${ }^{-1}$ ) was achieved under SS treatment in both 2016 and 2017, respectively (Table 4), and this might be due to lower bulk density for root penetration and build of soil nutrient. There was a lower yield under the ZT treatment (9.56 and 9.63\% lower) for 2016 and 2017, respectively, hence, some greater significant differences (Table 4). Yields are often compared through different tillage systems, and authors often report that a higher yield can be achieved with a conventional tillage in comparison with others tillage systems (reduced, conservation, and no-till or zero-till). According to Sartori and Peruzzi [65], corn cultivated with minimum tillage methods produced around $20-25 \%$ less than with those based on ploughing, while the yield reduction is even more obvious with no-tillage. Among conventional tillage, minimum tillage, and no-tillage in corn production, the highest yield had been obtained with the conventional tillage reported Borin and Sartori [66]. In the experiment during 1995-1996 in Croatia conditions, Zimmer et al. [67] reported that no-tillage achieved $4 \%$ less yield of corn in comparison with the conventional tillage.

Maximum 1000-grain weight (297.41 and $302.35 \mathrm{~g}$ ) was observed under the SS treatment for both years, and also highest dry matter (19.21 ton $\cdot \mathrm{ha}^{-1}$ ) was recorded under SS treatment (Table 4). Tillage practices significantly affected maize dry matter during both seasons (Table 4). During 2016, SS treatment was 7.50\% higher compared with ZT treatment. In 2017, dry matter under SS treatment was about 2.24, 3.67, and 7.62\% higher than with 2RT, 2RTSS, and ZT treatments, respectively. The highest dry matter may be attributed to higher plant height. This results strongly relate with Astier et al., Diaze-Zorita, Al-Kaisi and Licht, and Wasaya et al., [68-71], who reported that dry matter yield of maize improved due to good soil conditions provided to crop for better growth and development by loosening the soil with deep tillage or subsoiling (SS) implements.

There were no significant effects of different tillage treatments on maize harvest index (HI) in both years. However, SS treatment observed was 1.97 and $1.85 \%$ higher compared with ZT treatment in both years, respectively (Table 4). The results are closely associated with the findings of Patil and Sheelavantar [72] and Wasaya et al., [70], who observed the highest HI of maize grown in deeply tilled (subsoiling) plots, respectively.
The observed results pertaining to 1000-grain weight are illustrated in (Table 4). The results showed significant differences in 1000-grain weight between the different tillage treatments. SS treatment produced heavier grains compared to the other treatments. The maximum (297.41 and $302.35 \mathrm{~g}$ ) 1000-grain weight was observed under SS treatment, followed by 283.70 and $288.41 \mathrm{~g}$, and 277.11 and $281.54 \mathrm{~g}$, 2RT and 2RTSS treatment, while the lowest (270.14 and $272.22 \mathrm{~g}$ ) 1000 -grain weight was observed under ZT treatment for both years, respectively. The results are in agreement with those by Ahmad et al. [73]. According to them, significantly higher grain yields were produced under conventional tillage treatment as compared to zero tillage.

\section{Conclusion}

In this paper, the ZT treatment showed significantly higher organic $\mathrm{C}$ and nutrient levels in their available form than the other treatments, whereas the SS treatment had higher concentration of soil urease, catalase, and acid phosphatase. Also, maximum grain yield, dry matter, harvest index, and 1000 -grain yield were recorded under SS treatment. Overall, although ZT facilitated more organic $\mathrm{C}$ and available NPK, soil with ZT had lower soil enzyme and maize yield components compared to SS treatment, and therefore SS treatment could be exploited as a strategy for soil health and productivity resulting in a sustainable agricultural system.

\section{Data Availability}

The data used to support the findings of this study are available from the corresponding author upon request.

\section{Conflicts of Interest}

The authors declare that they have no conflicts of interest.

\section{Acknowledgments}

This work was supported by the National Key Research and Development Program of China (No. 2016YFD0700301) and the National Natural Science Foundation of China (No. 31601225).

\section{References}

[1] G. R. Maharijan, A. K. Prescher, C. Nendel et al., "Approach to model the impact of tillage implements on soil physical and nutrient properties in different agro-ecosystem models," Soil and Tillage Research, vol. 180, pp. 210-221, 2018.

[2] D. J. Connor and M. I. Mínguez, "Evolution not revolution of farming systems will best feed and green the world," Global Food Security, vol. 1, no. 2, pp. 106-113, 2012.

[3] J. A. Foley, N. Ramankutty, K. A. Brauman et al., "Solutions for a cultivated planet," Nature, vol. 478, no. 7369, pp. 337342, 2011.

[4] R. A. Robinson and W.J. Sutherland, "Post-war changes in arable farming and biodiversity in Great Britain," Journal of Applied Ecology, vol. 39, no. 1, pp. 157-176, 2002. 
[5] N. D. Uri, J. D. Atwood, and J. Sanabria, "The environmental benefits and costs of conservation tillage," Science of the Total Environment, vol. 216, no. 1-2, pp. 13-32, 1998.

[6] C. Stoate, A. Báldi, P. Beja et al., "Ecological impacts of early 21 st century agricultural change in Europe-a review," Journal of Environmental Management, vol. 91, no. 1, pp. 22-46, 2009.

[7] K. G. Cassman, A. Dobermann, D. T. Walters, and H. Yang, "Meeting cereal demand while protecting natural resources and improving environmental quality," Annual Review of Environment and Resources, vol. 28, no. 1, pp. 315-358, 2003.

[8] K. Köller, "Techniques of soil tillage," in Soil Tillage in Agroecosystems, A. El Titi, Ed., CRC Press, Boca Raton, FL, USA, 2003.

[9] J. Álvaro-Fuentes, F. J. Morell, E. Madejón, J. Lampurlanés, J. L. Arrúe, and C. Cantero-Martínez, "Soil biochemical properties in a semiarid Mediterranean agroecosystem as affected by long-term tillage and $\mathrm{N}$ fertilization," Soil and Tillage Research, vol. 129, pp. 69-74, 2013.

[10] A. Roldán, J. R. Salinas-García, M. M. Alguacil, and F. Caravaca, "Changes in soil enzyme activity, fertility, aggregation and $\mathrm{C}$ sequestration mediated by conservation tillage practices and water regime in a maize field," Applied Soil Ecology, vol. 30, no. 1, pp. 11-20, 2005.

[11] K. Willekens, B. Vandecasteele, D. Buchan, and S. De Neve, "Soil quality is positively affected by reduced tillage and compost in an intensive vegetable cropping system," Applied Soil Ecology, vol. 82, pp. 61-71, 2014.

[12] A. Chassot, P. Stamp, and W. Richner, "Root distribution and morphology of maize seedlings as affected by tillage and fertilizer placement," Plant and Soil, vol. 231, no. 1, pp. 123-135, 2001.

[13] A. Deubel, B. Hofmann, and D. Orzessek, "Long-term effects of tillage on stratification and plant availability of phosphate and potassium in a loess chernozem," Soil and Tillage Research, vol. 117, pp. 85-92, 2011.

[14] M. B. Villamil and E. D. Nafziger, "Corn residue, tillage, and nitrogen rate effects on soil carbon and nutrient stocks in Illinois," Geoderma, vol. 253-254, pp. 61-66, 2015.

[15] R. Alvarez and H. S. Steinbach, "A review of the effects of tillage systems on some soil physical properties, water content, nitrate availability and crops yield in the Argentine Pampas," Soil and Tillage Research, vol. 104, no. 1, pp. 1-15, 2009.

[16] V. Ćirić, M. Manojlović, L. Nešić, and M. Belić, "Soil dry aggregate size distribution: effects of soil type and land use," Journal of Soil Science and Plant Nutrition, vol. 12, no. 4, pp. 689-703, 2012.

[17] N. Dal Ferro, L. Sartori, G. Simonetti, A. Berti, and F. Morari, "Soil macro- and microstructure as affected by different tillage systems and their effects on maize root growth," Soil and Tillage Research, vol. 140, pp. 55-65, 2014.

[18] R. Derpsch, T. Friedrich, A. Kassam, and L. Hongwen, "Current status of adoption of no-till farming in the world and some of its main benefits," International Journal of Agriculture and Biological Engineering, vol. 3, no. 1, pp. 1-26, 2010.

[19] P. W. Unger, "Infiltration of simulated rainfall: tillage system and crop residue effects," Soil Science Society of American Journal, vol. 56, no. 1, pp. 283-289, 1992.

[20] É. F. M. Pinheiro, D. V. B. de Campos, F. de Carvalho Balieiro, L. H. C. dos Anjos, and M. G. Pereira, "Tillage systems effects on soil carbon stock and physical fractions of soil organic matter," Agricultural Systems, vol. 132, pp. 35-39, 2015.

[21] D. S. Powlson, A. Bhogal, B. J. Chambers et al., "The potential to increase soil carbon stocks through reduced tillage or organic material additions in England and Wales: a case study," Agricultural Ecosystem and Environment, vol. 146, no. 1, pp. 23-33, 2012.

[22] P. Schjønning and I. K. Thomsen, "Shallow tillage effects on soil properties for temperate-region hard-setting soils," Soil and Tillage Research, vol. 132, pp. 12-20, 2013.

[23] I. Vogeler, J. Rogasik, U. Funder, K. Panten, and E. Schnug, "Effect of tillage systems and P-fertilization on soil physical and chemical properties, crop yield and nutrient uptake," Soil and Tillage Research, vol. 103, no. 1, pp. 137-143, 2009.

[24] C. J. Bronick and R. Lal, "Soil structure and management: a review," Geoderma, vol. 124, no. 1-2, pp. 3-22, 2005.

[25] C. A. Cambardella and E. T. Elliott, "Particulate soil organicmatter changes across a grassland cultivation sequence," Soil Science Society of American Journal, vol. 56, no. 3, pp. 777783, 1992.

[26] A. Calegari, T. Tiecher, W. L. Hargrove et al., "Long-term effect of different soil management systems and winter crops on soil acidity and vertical distribution of nutrients in a Brazilian Oxisol," Soil and Tillage Research, vol. 133, pp. 32-39, 2013.

[27] H. Spiegel, G. Dersch, J. Hösch, and A. Baumgarten, “Tillage effects on soil organic carbon and nutrient availability in a long-term field experiment in Austria," Bodenkultur, vol. 58, no. 1, pp. 47-58, 2007.

[28] M. X. Gómez-Rey, A. Couto-Vázquez, and S. J. GonzálezPrieto, "Nitrogen transformation rates and nutrient availability under conventional plough and conservation tillage," Soil Tillage Research, vol. 124, pp. 144-152, 2012.

[29] Q. Ji, Y. Wang, X. N. Chen, and X. D. Wang, "Tillage effects on soil aggregation, organic carbon fractions and grain yield in Eum-Orthic anthrosol of a winter wheat-maize doublecropping system, Northwest China," Soil Use Management, vol. 31, no. 4, pp. 504-514, 2015.

[30] C. López-Fando and M. T. Pardo, "Use of a partial-width tillage system maintains benefits of no-tillage in increasing total soil nitrogen," Soil and Tillage Research, vol. 118, pp. 32-39, 2012.

[31] R. G. Bates, Glass Electrodes. Determination of $p H$, Wiley, Hoboken, NJ, USA, 1954.

[32] C. A. Black, Methods of Soil Analysis, American Society of Agronomy, Madison, WI, USA, 1973.

[33] P. L. Searle and T. W. Speir, "An automated colorimetric method for the determination of urease activity in soil and plant material," Communication in Soil Science and Plant Analysis, vol. 7, no. 4, pp. 365-374, 1976.

[34] L. A. Douglas and J. M. Bremner, "Colorimetric determination of microgram quantities of urea," Analytical Letters, vol. 3, no. 2, pp. 79-87, 1970.

[35] S.-Y. Guan and G.-Q. Shen, "Enzyme activities in main soil in China," Acta Pedologica Sinica, vol. 21, no. 4, pp. 368-381, 1984.

[36] M. A. Tabatabai and J. M. Bremner, "Use of phenyl diphenyl phosphate for assay of phosphatase activity," Soil Biology and Biochemistry, vol. 1, no. 4, pp. 301-307, 1969.

[37] C. S. Yan, Research Methods of Soil Fertility, Chinese Agricultural Press, Beijing, China, 1988.

[38] S. D. Bao, Soil and Agricultural Chemistry Analysis, Chinese Agricultural Publishing House, Beijing, China, 2005.

[39] R. H. Bray and L. T. Kurtz, "Determination of total, organic, and available forms of phosphorus in soils," Soil Science, vol. 59, no. 1, pp. 39-45, 1945.

[40] C.L. Whittles and R. C. Little, "A colorimetric method for determination of potassium and its application on the analysis of soil extracts," Journal of the Science of Food and Agriculture, vol. 1, no. 11, pp. 323-329, 1950. 
[41] R. G. D. Steel and J. H. Torrie, Principles of Statistics. A Biometrical Approach, McGraw-Hill, New York, NY, USA, 2nd edition, 1980.

[42] K. Kovac and S. Zak, "Influence of various ways of soil cultivation on selected physical properties," Vedecke Prace, vol. 29, pp. 13-22, 1999.

[43] D. Filipovic, S. Husnjak, S. Kosutic, and Z. Gospodaric, "Effects of tillage systems on compaction and crop yield of Albic Luvisol in Croatia," Journal of Terramechanics, vol. 43, no. 2, pp. 177-189, 2006.

[44] A. Butorac, F. Basic, I. Tursic, and M. Mesic, "The response of some field crops to soil compaction," in Proceedings of 12th ISTRO conference, pp. 276-85, Tallin, Estonia, 1992.

[45] E. C. Varsa, S. K. Chong, J. O. Abolaji, D. A. Farquhar, and F. J. Olsen, "Effect of deep tillage on soil physical characteristic and corn (Zea mays L.) root growth and production," Soil and Tillage Research, vol. 43, no. 3-4, pp. 219-228, 1997.

[46] R. J. Roseberg and E. L. McCoy, "Tillage and traffic-induced changes in macro-porosity and macro-porosity community: air permeability assessment," Soil Science Society of America Journal, vol. 56, no. 4, pp. 1261-1267, 1992.

[47] M. T. Oliveira and I. A. Merwin, "Soil physical conditions in a New York orchard after eight years under different groundcover management systems," Plant and Soil, vol. 234, no. 2, pp. 233-237, 2001.

[48] A. M. Falatah and A. M. Al-Derby, "Chemical properties of a calcareous soil as affected by tillage practices in Saudi Arabia," Arid Soil Research and Rehabilitation, vol. 7, no. 4, pp. 347-353, 1993.

[49] A. J. Franzluebbers and F. M. Hons, "Soil profile distribution of primary and secondary plant available nutrients under conventional and no tillage," Soil and Tillage Research, vol. 39, no. 3-4, pp. 229-239, 1996.

[50] I. Martin-Rueda, L. M. Munoz-Guerra, F. Yunta, E. Esteban, J. L. Tenorio, and J. J. Lucena, "Tillage and crop rotation effects on barley yield and soil nutrients on a Calciortidic haploxeralf," Soil and Tillage Research, vol. 92, no. 1-2, pp. 1-9, 2007.

[51] D. J. Horne, C. W. Ross, and K. A. Hughes, "Ten years of maize/oats rotation under three tillage systems on silt loam in New Zealand. 1. A comparison of some soil physical and chemical properties," Soil and Tillage Research, vol. 22, no. 12, pp. 131-143, 1992.

[52] M. Abid and R. Lal, "Tillage and drainage impact on soil quality-I. Aggregate stability, carbon and nitrogen pools," Soil and Tillage Research, vol. 100, no. 1-2, pp. 89-98, 2008.

[53] J. Six, E. T. Elliot, K. Paustian, and J. W. Doran, “Aggregation and soil organic matter accumulation in cultivated and native grassland soils," Soil Science Society of America Journal, vol. 62, no. 5, pp. 1367-1377, 1998.

[54] S. S. Malhi, C. A. Grant, A.M. Johnston, and K. S. Gill, "Nitrogen fertilization management for no-till cereal production in the Canadian Great Plains: a review," Soil and Tillage Research, vol. 60, no. 3-4, pp. 101-122, 2001.

[55] L. M. Zibilske, J. M. Bradford, and J. R. Smart, "Conservation tillage induced changes in organic carbon, total nitrogen and available phosphorus in a semi-arid alkaline subtropical soil," Soil and Tillage Research, vol. 66, no. 2, pp. 153-163, 2002.

[56] Y. D. Redel, R. Rubio, J. L. Rouanet, and F. Borie, "Phosphorus bioavailability affected by tillage and crop rotation on a Chilean volcanic derived Ultisol," Geoderma, vol. 139, no. 34, pp. 388-396, 2007.

[57] D. D. Rheinheimer and I. Anghinoni, "Accumulation of soil organic phosphorus by soil tillage and cropping systems under subtropical conditions," Communication in Soil Science and Plant Analysis, vol. 34, no. 15-16, pp. 2339-2354, 2003.

[58] S. Phiri, E. Barrios, I. M. Rao, and B. R. Singh, "Changes in soil organic matter and phosphorus fractions under planted fallows and a crop rotation system on a Colombian volcanic-ash soil," Plant and Soil, vol. 231, no. 2, pp. 211-223, 2001.

[59] A. A. Mahboubi, R. Lar, and N. R. Faussey, "Twenty-eight years of tillage effects on two soils in Ohio," Soil Science Society of America Journal, vol. 57, no. 2, pp. 506-512, 1993.

[60] X. Yin and T. J. Vyn, "Residual effects of potassium placement and tillage systems for corn on subsequent no-till soybean," Agronomy Journal, vol. 94, no. 5, pp. 1112-1119, 2002.

[61] E. J. Kladivko, "Tillage systems and soil ecology," Soil and Tillage Research, vol. 61, no. 1-2, pp. 61-76, 2001.

[62] K. Jin, S. Sleutel, D. Buchan et al., "Changes of soil enzyme activities under different tillage practices in the Chinese Loess Plateau," Soil and Tillage Research, vol. 104, no. 1, pp. 115-120, 2009.

[63] H. Kheyrodin, K. Ghazvinian, and M. Taherin, "Tillage and manure effect on soil, microbial biomass and respiration, and on enzyme activities," African Journal of Biotechnology, vol. 11, no. 81, pp. 14652-14659, 2012.

[64] S. P. Deng and M. A. Tabatabai, "Effects of tillage and residue management on enzyme activities in soils: III. Phosphatases and arylsulfatase," Biology and Fertility of Soil, vol. 24, no. 2, pp. 141-146, 1997.

[65] L. Sartori and A. Peruzzi, "The evolution of no-tillage in Italy: a review of the scientific literature," in Experience with the Applicability of No-tillage Crop Production in the WestEuropean Countries, F. Tebrügge and A. Böhrnsen, Eds., Proceedings of 1st EC Workshop, pp. 119-130, Wissenschaftlicher Fachverlag, Giessen, Germany, June 1994.

[66] M. Borin and L. Sartori, "Barley, soybean and maize production using ridge tillage, no-tillage and conventional tillage in north-east Italy," Journal of Agricultural Engineering Research, vol. 62, no. 4, pp. 229-236, 1995.

[67] R. Zimmer, B. Milos, Z. Milakovic, and Z. Krzek, "Comparison of conventional and no-tillage in maize production," in Proceedings of 25th International Symposium Actual Tasks on Agricultural Engineering, pp. 155-160, Opatija, Croatia, 1997.

[68] M. Astier, J. M. Maas, J. D. Etchevers-Barra, J. J. Pena, and F. D. L. Gonzalez, "Short-term green manure and tillage management effects on maize yield and soil quality in an Andisol," Soil and Tillage Research, vol. 88, no. 1-2, pp. 153-159, 2006.

[69] M. Díaz-Zorita, "Effects of deep-tillage and nitrogen fertilization interactions on dry land corn (Zea mays L.) productivity," Soil and Tillage Research, vol. 54, no. 1-2, pp. 11-19, 2000.

[70] M. Al-Kaisi and M. A. Licht, "Effects of strip tillage on corn nitrogen uptake and residual nitrate accumulation compared with no-tillage and chisel plow," Agronomy Journal, vol. 96, no. 4, pp. 1164-1171, 2004.

[71] A. Wasaya, M. Tahir, A. Tanveer, and M. Yaseen, "Response of maize to tillage and nitrogen management," Journal of Animal and Plant Science, vol. 22, no. 2, pp. 452-456, 2012.

[72] S. L. Patil and M. N. Sheelavantar, "Effects of tillage depth, organic amendments and nitrogen on yield of winter sorghum on a Vertisol in south India," Journal of Sustainable Agriculture, vol. 33, no. 1, pp. 28-50, 2009.

[73] I. Ahmad, M. T. Jan, and M. Arif, "Tillage and nitrogen management impact on maize," Sarhad Journal of Agriculture, vol. 26, no. 2, pp. 157-167, 2010. 

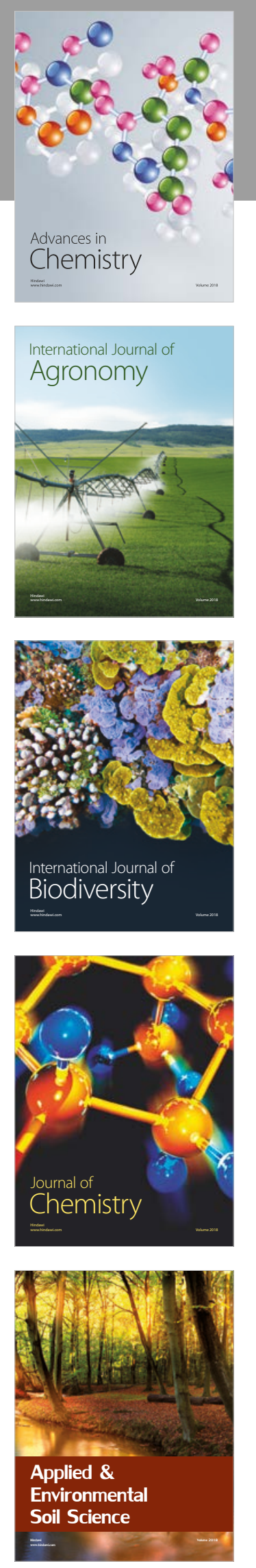

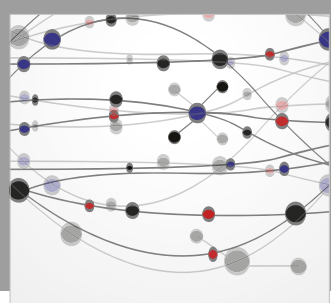

The Scientific World Journal

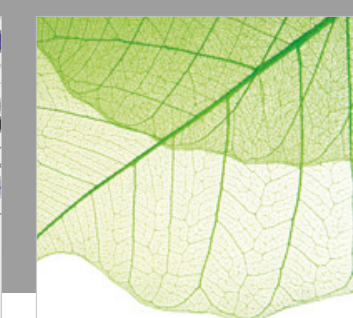

Journal of Botany

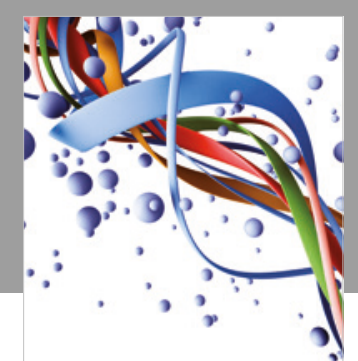

Scientifica

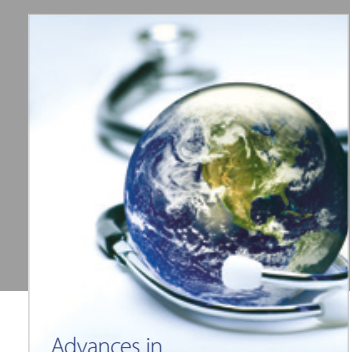

Public Health

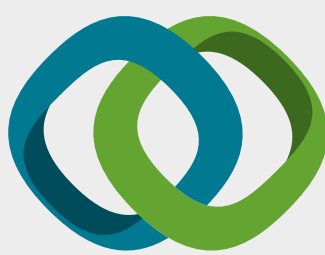

Hindawi

Submit your manuscripts at

www.hindawi.com
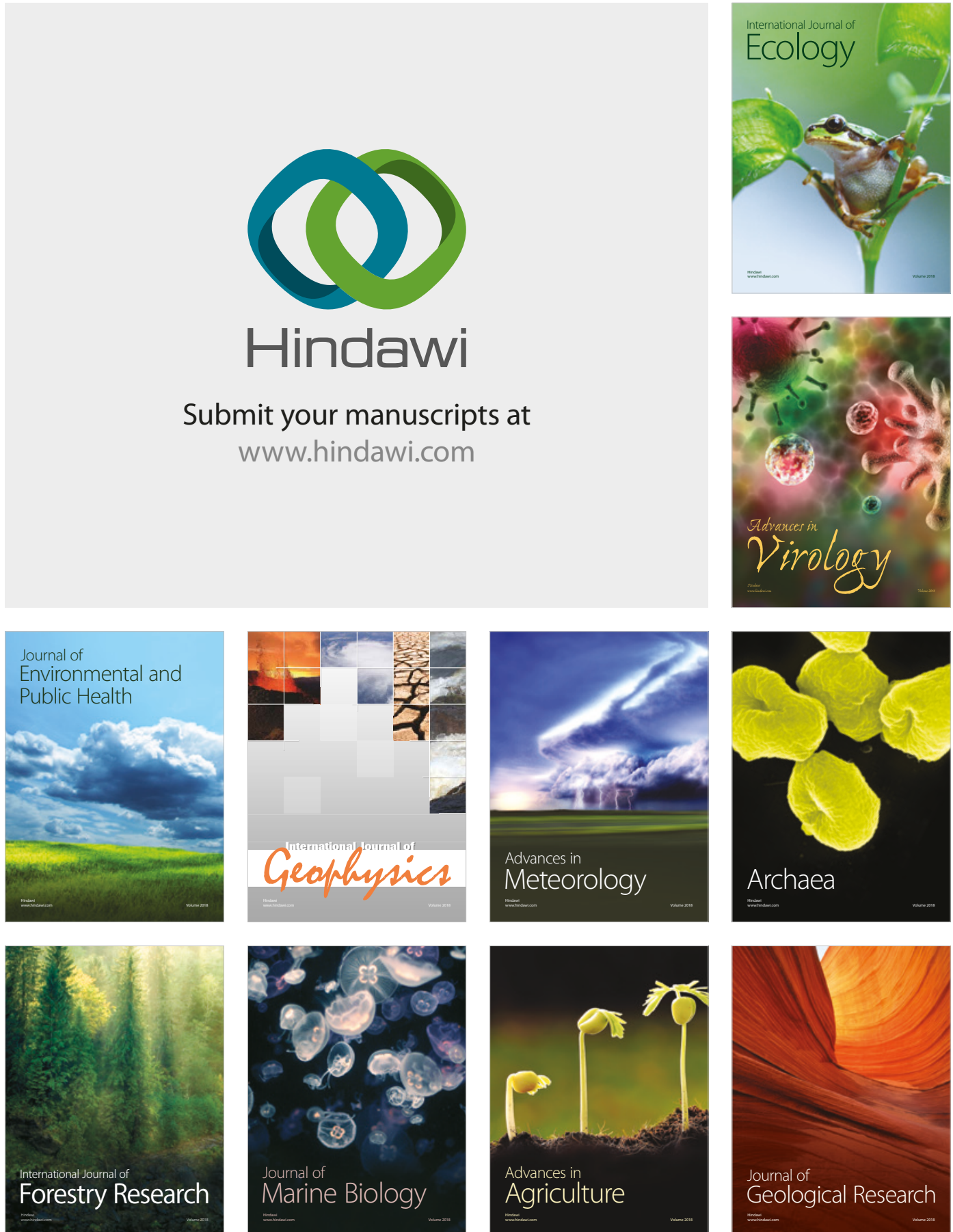

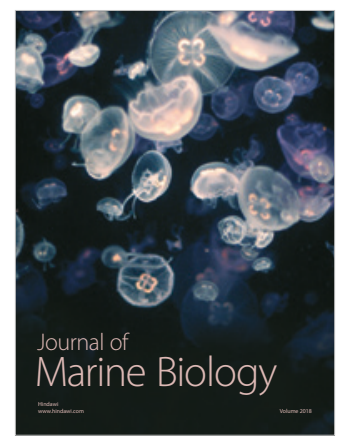

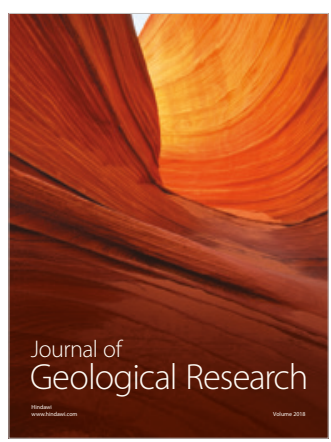

